Embryonic stem cells: don't let litigation put research off limits

Judge Royce Lamberth's order to stop US federally funded research on human embryonic stem cells sets a troubling precedent for intrusion into science in the name of law (Nature 467, 7 and 12; 2010). To make certain areas of research off limits is akin to our earlier obsession with Earth's central position in the Universe and its anthropocentric implications.

Science is about free competition of ideas; a good idea should not be suppressed. By resorting to litigation, the plaintiff researchers, James Sherley and Theresa Deisher, have betrayed the scientific principles they upheld when they received their $\mathrm{PhDs}$.

We need a more complete understanding of the unicellular state of a fertilized egg before we can decipher human biology and cure disease. This common operating principle, from the unifying point of a single cell, is key to unforeseen discoveries with tremendous potential benefit.

A nation that aspires for equal protection under law and imposes no law regarding religion should not allow science to be stopped by ideologically driven litigation. Jian Feng Department of Physiology and Biophysics, State University of New York at Buffalo, 124 Sherman Hall, Buffalo, New York 14214, USA e-mail: jianfeng@buffalo.edu

\section{Embryonic stem cells: court decision a threat to science itself}

I reluctantly concur with the point made by the plaintiffs' counsel Samuel Casey (Nature 467, 27; 2010) that the court's decision to stop human embryonic stemcell research is not a threat to the federal funding of science. No, allowing research agendas to be dictated by religious fundamentalists threatens the very enterprise of federally funded science itself.

Gordon Cash 3106 Castleton Court, Oakton, Virginia 22124, USA e-mail:ppp-cash@crosslink.net

\section{How nanotechnology captured the public imagination}

I would like to offer some crucial background about the US National Nanotechnology Initiative (Nature 467, 18-21; 2010).

A decade or so before the initiative was founded, advocates such as K. Eric Drexler and other exploratory engineers helped to develop nanotechnology as a concept and to bring it to a wider audience. Sciencefiction writers, including Greg Bear and Neal Stephenson, had written award-winning books that used speculative takes on nanotechnology to capture the public imagination. These contributions arguably smoothed the way for the initiative.

Although Drexlerian ideas were unpopular with some science managers and researchers, they influenced the thinking of people like Richard Smalley from the early 1990s - the Nobel laureate even sent copies of Drexler's books to potential patrons. Without them, nanotechnology could not have secured the traction it did in 2000.

Scientists in the United States who paved the way for the initiative included those at Cornell University's National Research and Resource Facility for Submicron Structures and the various NSF-funded materials-science laboratories. There were also active programmes in the United Kingdom and Japan years before the US initiative came along.

Readers might wonder whether nanotechnology was just a rebranding of previous research initiatives and whether other fields suffered as a result of the funding poured into it, not to mention how science managers such as Mihail
Roco and his colleagues came to make the case for a national nanotechnology initiative, and whether corporations were involved in the decision-making.

Recognizing the role of unexpected ideas and assorted actors in forming policy initiatives is important at a time when major programmes are being launched in new fields, including in synthetic biology, sustainable energy, stem-cell therapy, geoengineering and fusion research.

Patrick McCray NSF Center for Nanotechnology in Society, Department of History, University of California, Santa Barbara, California 93106, USA

e-mail:pmccray@cns.ucsb.edu

\section{Commodities for export still threaten rainforests in Brazil}

We find your conclusion premature that there is no longer a direct correlation between food production in Brazil and deforestation in the Amazon (Nature 466, 554-556; 2010).

An increase in demand by international markets for export commodities such as soya beans and beef will mean more rainforest clearance. There is still potential for a huge increase in productivity, given that large producers of export goods are encouraged by government loans at favourable rates and fiscally exempt debt relief, which in turn attract investment in research and development.

Moreover, Brazil's Congress has proposed large structural changes to the Forest Code that could lead to further deforestation and threaten the preservation of the most important Brazilian biomes.

Brazil's own staple crops - rice, beans and cassava - account for very little deforestation. The small farmers producing these still suffer low credit and heavy debts, fragile land tenure, scant investment in crop research, and inferior storage conditions for their products.
A global farm should be socially fair as well as environmentally friendly. Although Brazilian agricultural policy is on the way to meeting these conditions, we are not yet there.

Luiz Antonio Martinelli Centro de Energia Nuclear na Agricultura, Universidade de São Paulo, Piracicaba, 13416-000 Sao Paulo, Brazil; and Stanford University, Stanford, California 94305, USA e-mail:martinelli@cena.usp.br Paulo Moutinho Instituto de Pesquisa Ambiental da Amazônia, Brasília, 71503-505 Distrito Federal, Brazil

\section{Low repopulation of poor districts in New Orleans proves little}

John Mutter asserts that Hurricane Katrina hit the poor hardest (Nature 466, 1042;

2010). This seems plausible, so it is surprising that his evidence is weak and also consistent with other hypotheses.

Low repopulation of poor districts tells us nothing about the fate of poor people, who may have been glad to use the insurance payouts and federal assistance to leave such areas. It is people, not places, that count.

The fact that poor workers were more likely to lose their preKatrina jobs does not reveal their statuses now - job losses may be a natural consequence of inner-city depopulation. Even under normal circumstances, US job turnover is around 5\% per month. Turnover is usually several times higher than job destruction (see go.nature. com/JXJPtC) and is probably higher for unskilled workers.

Likewise, the $38 \%$ reduction in hospital beds after Katrina may not have hurt poor people disproportionately, especially if their neighbourhoods have experienced the $76 \%$ depopulation that Mutter cites.

Neal Hockley School of Environment, Natural Resources and Geography, Bangor University, Bangor, Gwynedd LL57 2UW, UK e-mail:n.hockley@bangor.ac.uk 